\title{
KONDISI SOSIAL EKONOMI BURUH PEREMPUAN PT. MITRATANI DUA TUJUH KABUPATEN JEMBER
}

\author{
Deliana Aristantia ${ }^{1}$, Sukidin ${ }^{1}$, Wiwin Hartanto ${ }^{1}$ \\ ${ }^{1}$ Program Studi Pendidikan Ekonomi, Fakultas Keguruan dan Ilmu Pendidikan Universitas Jember \\ E-mail: adeliaarista76@gmail.com
}

\begin{abstract}
Abstrak
Perempuan bekerja di sektor informal karena tidak membutuhkan pendidikan tinggi. Sektor informal memiliki waktu yang fleksibel dan tidak mempunyai banyak syarat untuk memasukinya. Jenis pekerjaan yang tidak membutuhkan pendidikan tinggi dan syarat untuk memasukinya salah satunya yaitu sebagai buruh. Penelitian ini bertujuan untuk mengetahui kondisi sosial ekonomi pada buruh perempuan PT. Mitratani Dua Tujuh. Penelitian ini termasuk penelitian kualitatif. Penentuan daerah penelitian dan informan menggunakan metode purposive Adapun untuk memperoleh data peneliti menggunakan metode wawancara sebagai metode utama, serta observasi dan dokumen sebagai data pelengkap. Data yang terkumpul dianalisis menggunakan analisis deksriptif kualitatif. Hasil penelitian menunjukkan bahwa kondisi sosial ekonomi buruh perempuan yang bekerja di bagian grading PT. Mitratani Dua Tujuh dapat dilihat dari 4 indikator yaitu pendidikan, pendapatan, tempat tinggal dan alat transportasi termasuk golongan kondisi sosial ekonomi sedang. Kondisi ekonomi informan dilihat dari indicator pendidikan yaitu termasuk golongan kondisi sosial ekonomi sedang, buruh perempuan yang bekerja di PT. Mitratani Dua Tujuh rata-rata lulusan SD hingga SMA. Pendapatan buruh perempuan di PT. Mitratani Dua Tujuh rata-rata masih dibawah UMK Kabupaten Jember sebesar Rp 2.170.917 yaitu bekisar Rp 1.536.000, namun dengan pendapatan tersebut dapat dinilai masih mencukupi kebutuhan keluarga sehari-hari. Kondisi tempat tinggal buruh perempuan di PT. Mitratani Dua Tujuh yaitu kondisi bangunan permanen, status kepemilikan ada yang milik sendiri dan orang tua serta luas bangunan rata-rata 36 m2. Alat transportasi yang digunakan buruh perempuan di PT. Mitratani Dua Tujuh yaitu sepeda motor, angkutan umum dan sepeda onthel.
\end{abstract}

Kata Kunci: Buruh Perempuan, Sosial Ekonomi

\section{PENDAHULUAN}

Secara umum perempuan banyak bekerja di sektor informal. Ciri sektor informal adalah tidak membutuhkan pendidikan tinggi. Sektor informal memiliki waktu yang fleksibel dan tidak mempunyai banyak syarat untuk memasukinya. (Bambang dan Mukhlis dalam Dewi, 2012: 120). Alasan lain perempuan memilih bekerja sebagai pekerja sektor informal adalah tidak tersedianya lapangan pekerjaan yang sesuai dengan tingkat pendidikan perempuan. Jenis pekerjaan yang tidak membutuhkan pendidikan tinggi dan syarat untuk memasukinya salah satunya yaitu sebagai buruh.

Buruh perempuan yang bekerja dihadapkan dengan dua tuntutan peran, yaitu sebagai ibu rumah tangga dan sebagai pencari nafkah. Kedua peran tersebut merupakan kewajiban dan tanggung jawab yang harus dilakukan secara bersamaan dengan optimal. Namun seringkali keadaan tersebut menimbulkan konflik yang cukup berat dari dalam diri seorang buruh perempuan. Beberapa konflik yang dialami buruh perempuan biasanya terkait pekerjaan dan keluarga. Pekerjaan sebagai buruh tidak memerlukan pendidikan tinggi dan memiliki keahlian atau ketrampilan khusus sehingga banyak wanita yang mendaftar bekerja di PT. Mitratani Dua Tujuh. Pekerjaan buruh perempuan ini terikat oleh jam kerja untuk mengejar target produksi.

Menurut Sumarsono (dalam Pratomo dan Saputra 2011: 269), untuk meningkatkan kehidupan yang layak khususnya bagi para pekerja terkait dengan kondisi ekonomi dapat dilakukan dengan menetapkan kebijakan upah minimum. Kebijakan Upah Minimum telah menjadi isu yang penting dalam masalah ketenagakerjaan di beberapa negara baik maju maupun berkembang. Sasaran dari kebijakan upah minimum ini adalah untuk menutupi kebutuhan hidup minimum dari pekerja dan keluarganya. Dengan demikian, kebijakan upah minimum adalah untuk (a) menjamin penghasilan pekerja sehingga tidak lebih rendah dari suatu tingkat tertentu, (b) meningkatkan produktivitas pekerja, (c) mengembangkan dan meningkatkan perusahaan dengan cara-cara produksi yang lebih efisien. Upah Minimum Kabupaten/Kota Jember yang ditetapkan sebesar Rp 2.170.917 berdasarkan Surat Keputusan Gubernur Jawa Timur Nomor 188/665/KPTS/013/2018. Pendapatan yang diterima pekerja wanita disesuaikan dengan jumlah kehadiran. Pendapatan yang diterima buruh perempuan ini harus sesuai dengan UMK yang berlaku. Tingkat besar kecilnya pendapatan yang diterima oleh tenaga kerja wanita ini berpengaruh terhadap pemanfaatan pendapatan yang diberikan kepada keluarganya. Semakin besar tingkat pendapatan yang diterima oleh tenaga kerja wanita ini maka semakin besar pula tingkat pemanfaatan pendapatan yang diberikan kepada keluarganya. 
Kondisi sosial masyarakat mempunyai beberapa indikator yaitu: umur dan jenis kelamin, pendidikan, pekerjaan, prestise (kemampuan), keluarga atau kelompok rumah tangga, dan keanggotaan dalam kelompok tertentu (organisasi) (Dalyono 2005:133). Kondisi ekonomi adalah suatu kedudukan yang secara rasional dan menetapkan seseorang pada posisi tertentu dalam masyarakat, pemberian posisi itu disertai pula dengan seperangkat hak dan kewajiban yang harus dimainkan oleh si pembawa status. Adapun indikator yang termasuk dalam kondisi ekonomi mencakup berbagai hal yang berkaitan erat dengan pemenuhan kebutuhan seperti pekerjaan, pendapatan, pengeluaran, kesehatan, kepemilikan aset, kredit / pinjaman (Basrowi dan Juariyah, 2010: 61).

PT. Mitratani Dua Tujuh merupakan salah satu perusahaan bergerak di bidang agribisnis yang mendukung program peningkatan perekonomian secara nasional. Perusahaan ini juga berkomitmen untuk menjadi suatu perusahaan yang dapat memberikan kontribusi pada pembangunan nasional. Mengingat juga perusahaan dapat menghasilkan devisa negara dan dapat menyediakan lapangan pekerjaan. Produk yang dihasilkan perusahaan ini adalah kedelai Jepang atau Edamame, okra, buncis serta aneka jenis sayur lainnya. Produk utama yang dihasilkan perusahaan ini adalah edamame. Yulyani (Ka.Divisi SDM) menjelaskan bahwa jumlah buruh yang bekerja di PT. Mitratani Dua Tujuh adalah buruh perempuan dengan jumlah kurang lebih 800 orang dan buruh laki-laki kurang lebih 100 orang. Buruh tersebut dipekerjakan di bagian grading, quality control dan packaging. Sistem pengupahan buruh ini dihitung per jam kerjanya. Jam kerja untuk bagian grading dimulai dari pukul 09.30-17.30 dengan waktu istirahat 1 jam dan jumlah jam kerja selama kurang lebih 7 jam dan jam kerja untuk packaging terdiri dari 2 shift yakni shift 1 dimulai dari pukul 06.00-14.00 dan shift 2 dimulai dari jam 14.0022.00 .

PT. Mitratani Dua Tujuh mengandalkan tenaga kerja perempuan dalam proses grading yakni proses pemisahan edamame menjadi 4 golongan, yaitu SQ (Standart Quality), SG(Second Grade),TG (Third Grad) dan BBM (Bahan Baku Mukimame). Mereka yang bekerja di PT. Mitratani Dua Tujuh memiliki bermacam-macam motivasi yang menuntut mereka harus bekerja disana salah satunya kondisi sosial ekonomi keluarganya. Keadaan suami mereka bekerja tidak tentu seperti buruh bangunan dan serabutan sehingga mereka beranggapan bahwa keluarga memiliki kebutuhan yang semakin banyak, dan tidak semua dari kebutuhan tersebut dapat dipenuhi dari penghasilan suami, serta naiknya harga kebutuhan pokok yang cukup tinggi membuat perempuan bekerja menjadi buruh di PT. Mitratani Dua Tujuh. Selain itu, bekerja menjadi buruh tidak membutuhkan pendidikan tinggi dan banyak syarat untuk memasukinya. Pendidikan yang ditempuh buruh di PT. Mitra Tani Dua Tujuh Jember ada yang tidak bersekolah hingga Sekolah Menengah Atas (SMA). Upah yang diterima oleh buruh perempuan per hari yaitu sebesar Rp 64.000,--

Untuk melihat kondisi sosial ekonomi masyarakat dapat dilihat melalui 3 aspek yaitu pekerjaan, pendidikan dan penghasilan. Berdasarkan hal tersebut, maka keluarga atau masyarakat dapat digolongkan memiliki sosial ekonomi rendah, sedang dan tinggi (Koejoningrat dalam Zunaidi, 2013:54). Kondisi sosial ekonomi yang akan diteliti pada buruh perempuan PT. Mitratani Dua Tujuh yaitu pendidikan, pendapatan, tempat tinggal, dan alat transportasi. Indikator pendidikan yang dilihat yaitu pendidikan formal yang ditempuh oleh seseorang. Indikator pendapatan yang dilihat yaitu pendapatan yang disesuaikan dengan upah minimum. Upah minimum disesuaikan Kebutuhan Hidup Layak (KHL). Kebutuhan Hidup Layak (KHL) adalah standar kebutuhan seseorang pekerja/buruh untuk dapat hidup layak secara fisik dalam 1 bulan (Peraturan Menteri Ketenagakerjaan No 21 Tahun 2016). Indikator tempat tinggal dapat dilihat dari: a) Status rumah yang ditempati, bisa rumah sendiri, rumah dinas, menyewa, menumpang pada saudara atau ikut orang lain; b) Kondisi fisik bangunan dapat berupa permanen, kayu dan bambu; c) Besarnya rumah yang ditempati, semakin luas rumah yang ditempati pada umumya semakin tinggi tingkat sosial ekonominya. Ciri rumah yang tergolong permanen yakni bangunan rumah yang sudah kokoh, dindingnya terbuat dari tembok, lantainya terbuat dari keramik dan atapnya terbuat dari genteng (Sumardi dalam Wijianto dan Ulfa, 2016: 194). Indikator alat transportasi meliputi kepemilikan alat transportasi, fasilitas alat transportasi serta ongkos dan biaya (Badan Pusat Statistik, 2003). Penelitian ini bertujuan untuk mengetahui kehidupan sosial ekonomi keluarga buruh perempuan yang terdiri dari 4 indikator yaitu pendidikan, pendapatan, tempat tinggal dan alat transportasi.

\section{METODE PENELITIAN}

Penelitian ini merupakan penelitian kualitatif. Creswell (dalam Semiawan, 2010: 7) mendefinisikan metode penelitian kualitatif sebagai suatu pendekatan atau penelusuran untuk mengeksplorasi dan memahami suatu gejala sentral. Untuk mengerti gejala sentral tersebut peneliti mewawancarai peserta penelitian atau partisipan dengan mengajukan pertanyaan yang umum dan agak luas. Informasi yang disampaikan oleh partisipan kemudian dikumpulkan. Informasi tersebut biasanya berupa kata atau teks. Data yang berupa kata-kata atau teks tersebut dianalisis. Hasil analisis tersebut dapat berupa penggambaran atau deskripsi dan menginterpretasikan. Penentuan lokasi penelitian menggunakan metode purposive area. Metode penentuan informan menggunakan metode purposive. Adapun untuk memperoleh data peneliti menggunakan metode wawancara sebagai metode 
utama, serta observasi dan dokumen sebagai metode pelengkap. Data yang terkumpul dianalisis menggunakan analisis deksriptif

\section{HASIL DAN PEMBAHASAN \\ Hasil Penelitian}

Kondisi sosial ekonomi buruh perempuan yang dibahas dalam penelitian ini adalah sebagai berikut:

\section{Pendidikan}

Rendahnya pendidikan yang dimiliki informan menyebabkan informan bekerja menjadi buruh perempuan di bagian grading PT. Mitratani Dua Tujuh. Pekerjaan buruh bagian grading di PT. Mitratani Dua Tujuh tidak membutuhkan pendidikan tinggi dan keahlian khusus sehingga mudah bagi informan untuk bekerja di bagian grading. Tingkat pendidikan informan dapat disajikan pada Tabel 1 :

\section{Tabel 1. Pendidikan Informan}

\begin{tabular}{|l|l|l|}
\hline No & Nama & Pendidikan \\
\hline 1 & SH & SMP \\
\hline 2 & SC & SMP \\
\hline 3 & VI & SMA \\
\hline 4 & IK & SMA \\
\hline 5 & SP & SMA \\
\hline 6 & RM & SD \\
\hline
\end{tabular}

Sumber: Data Primer diolah, 2018

Tabel 1 dapat diketahui tingkat pendidikan tertinggi informan penelitian yaitu tamat SMA dan tingkat pendidikan terendahnya yaitu tamat SD. Informan yang memiliki pendidikan tamat SMA yaitu VI, IK dan SP. Informan yang memiliki pendidikan tamat SMP yaitu SH dan SC. Informan yang memiliki pendidikan tamat SD yaitu Romlah. PT. Mitratani Dua Tujuh dalam merekrut pekerja juga mempertimbangkan tingkat pendidikannya yakni minimal SMA, namun dapat memungkiri juga PT. Mitratani Dua Tujuh merekrut pekerja dengan pendidikan dibawah tamatan SMA. Hal tersebut relevan dengan pekerjaan yang dilakukan, sebab untuk menjadi pekerja bagian grading tidak harus memiliki pendidikan yang tinggi hanya membutuhkan ketekunan dan ketelatenan dalam bekerja.

Pendidikan informan penelitian menunjukkan bahwa tingkat pendidikan buruh perempuan bagian grading PT. Mitratani Dua Tujuh dikategorikan tingkat pendidikannya rendah. Pendidikan merupakan hal yang penting untuk meningkatkan pengetahuan seseorang. Ada beberapa faktor yang menyebabkan individu tidak mengenyam pendidikan tinggi seperti tidak ada sarana sekolah di desa, ekonomi atau kondisi psikologis individu. Namun, rendahnya pendidikan yang dimiliki oleh individu tidak membatasi dan membuat individu memiliki pengetahuan yang tertinggal. Informan penelitian memiliki orientasi pandangan ke depan mengenai pendidikan untuk anaknya. Informan memahami bahwa pendidikan itu penting. Informan juga berharap anaknya kelak menempuh jenjang pendidikan tinggi agar bisa menjamin karir dan ekonomi masa depan anaknya kelak.

2. Pendapatan

Pendapatan dalam penelitian ini merupakan jumlah upah yang diterima buruh perempuan selama 1 bulan. Sistem pengupahan buruh perempuan bagian grading tidak berdasarkan strata pendidikannya. Upah buruh perempuan diberlakukan sama walaupun pendidikan buruh perempuan yang berbeda-beda. Lama kerja buruh perempuan pun tidak menjamin buruh perempuan tersebut dianggap menjadi buruh tetap dan upah meningkat. Status buruh perempuan dalam PT. Mitratani Dua Tujuh yaitu pekerja lepas sehingga penerimaan upah disesuaikan dengan banyaknya hari kerja. Lama tidaknya buruh perempuan bekerja tergantung dari masing-masing buruh, jika buruh tidak ingin melanjutkan pekerjaan perusahaan tidak menghalangi buruh. Upah buruh perempuan yaitu Rp 64.000/hari dengan total 7 jam kerja dan jika buruh perempuan mengambil lembur diluar jumlah jam kerja mendapatkan tambahan upah Rp 10.000/jam. Ketika produksi edamame melimpah biasanya buruh diminta untuk bekerja lembur. Kedelai edamame PT. Mitratani Dua Tujuh biasaya di panen pada saat 80-90 hari. Lembur buruh biasanya setiap 3 bulan sekali disesuaikan dengan panen kedelai. Sistem kerja lembur ini diberlakukan kepada semua buruh, jika mau mengambil lembur dipersilahkan dan tidak ada pemaksaan. Perhitungan upah buruh lembur buruh dihitung per tambahan jam yang diambil buruh. Pendapatan yang diperoleh informan dan lama bekerja informan dapat disajikan pada sebagai berikut:

Tabel 2. Lama Bekerja dan Pendapatan Informan

\begin{tabular}{|l|l|l|l|}
\hline No & Nama & Lama bekerja (tahun) & Pendapatan (Rp/bulan) \\
\hline 1 & SH & 4 & 1.536 .000 \\
\hline 2 & SC & 2 & 1.536 .000 \\
\hline 3 & VI & 5 & 1.536 .000 \\
\hline 4 & IK & 1 & 1.792 .000 \\
\hline 5 & SP & 8 & 1.536 .000 \\
\hline
\end{tabular}


Jurnal Pendidikan Ekonomi: Jurnal Ilmiah Ilmu Pendidikan, Ilmu Ekonomi, dan Ilmu Sosial

\begin{tabular}{|l|l|l|l|r}
\hline 6 & RM Sumber: & 8 & 1.536 .000 & Sum
\end{tabular}

mer diolah, 2018

Data pri-

Tabel 2 menunjukkan bahwa pendapatan informan rata-rata sebesar Rp 1.536.000,- per bulan. Informan menerima upah sebesar Rp 64.000,-/hari dengan hari kerja 6-7 hari (7jam kerja). Sistem penggajian informan dibayarkan setiap seminggu sekali. Pendapatan dari informan IK berbeda dengan informan lainnya yaitu sebesar Rp 1.792.000,-. Hal tersebut disebabkan karena informan IK masih berstatus single dan mengambil 7 hari kerja dalam sebulan. Alasan informan bekerja menjadi buruh grading di PT. Mitratani Dua Tujuh yaitu karena banyaknya kebutuhan sehari-hari untuk membayar listrik, makan, biaya anak sekolah dan pendapatan yang diterima suami yang rendah.Rendahnya pendapatan suami sehingga tidak dapat mencukupi kebutuhan keluarga menyebabkan informan bergantung kepada PT. Mitratani Dua Tujuh dalam mencukupi kebutuhan keluarga. Hal tersebut terbukti dengan lama bekerja informan antara 1-8 tahun. Adanya pendapatan tambahan keluarga dari informan dapat membantu keluarga informan untuk mencukupi kebutuhan keluarga. Hasil penelitian menunjukkan pendapatan informan masih di bawah UMK Kabupaten Jember. Namun dengan pendapatan yang diperoleh dari bekerja sebagai buruh, informan mengatakan pendapatan tersebut cukup untuk memenuhi kebutuhan keluarga sehari-hari. 3. Tempat tinggal

Kondisi sosial ekonomi dapat dilihat dari tempat tinggal dengan karakteristik: a) status rumah yang ditempati, bisa rumah sendiri, rumah dinas, menyewa, menumpang pada saudara atau ikut orang lain; dan b) kondisi fisik bangunan dapat berupa permanen, kayu dan bambu. Kondisi tempat tinggal dan status kepemilikan rumah dapat disajikan pada tabel di bawah:

Tabel 3. Kondisi Tempat Tinggal Informan

\begin{tabular}{|l|l|l|l|}
\hline No & Nama & Kondisi Rumah & Status Kepemilikan \\
\hline 1 & SH & Permanen & Sendiri \\
\hline 2 & SC & Permanen & Orang tua \\
\hline 3 & VI & Permanen & Sendiri \\
\hline 4 & IK & Permanen & Tinggal bersama \\
\hline 5 & SP & Permanen & Sendiri \\
\hline 6 & RM & Permanen & Sendiri \\
\hline
\end{tabular}

Sumber: Data Primer diolah, 2018

Kondisi tempat tinggal informan berdasarkan Tabel 3 yaitu permanen. Ciri rumah yang tergolong permanen yakni bangunan rumah yang sudah kokoh, dindingnya terbuat dari tembok, lantainya terbuat dari keramik dan atapnya terbuat dari genteng. Status kepemilikan tempat tinggal informan ada yang sudah rumah sendiri, milik orang tua, dan ada yang masih tinggal bersama orang tua. Kondisi dan status kepemilikan rumah informan berkaitan erat dengan pendapatan yang diterima keluarga dan lama bekerja informan. Informan yang memiliki lama bekerja 4-8 tahun yaitu SH, VI, SP dan RM memiliki kondisi rumah permanen dengan status kepemilikan milik sendiri. Hal tersebut menunjukkan selama informan bekerja di PT. Mitratani Dua Tujuh, informan dapat membantu keluarga untuk mencukupi kebutuhan keluarga salah satunya kebutuhan papan.

Hasil penelitian menunjukan kondisi rumah informan menunjukkan luas bangunan rumah informan ratarata seluas $36 \mathrm{~m} 2$ dengan kondisinya permanen yaitu bangunan rumah yang sudah kokoh, dindingnya terbuat dari tembok, lantainya terbuat dari keramik dan atapnya terbuat dari genteng. Selain itu, status kepemilikan rumah informan bervariasi yakni ada yang rumah milik sendiri dan tinggal bersama orang tua. Luas minimal bangunan yang ditetapkan Kementerian PUPR ( Pekerjaan Umum dan Perumahan Rakyat) yaitu 36 m2 yang menunjukkan bahwa luas bangunan rumah sederhana yang layak dihuni artinya kondisi rumah informan dapat dikatakan layak huni.

\section{Alat Transportasi}

Alat transportasi dalam penelitian ini mendeskripsikan jenis transportasi yang dimiliki, status kepemilikan transportasi dan kemudahan dalam mengakses transportasi umum. Alat transportasi dapat mempermudah informan dalam mobilitas sehari-hari. Informan dapat menggunakan sepeda motor atau angkutan umum untuk mempermudah informan dalam mobilitas ke tempat kerja.

Tabel 4. Alat Trasnportasi yang Digunakan Informan

\begin{tabular}{|l|l|l|}
\hline No & Nama & Kendaraan yang digunakan \\
\hline 1 & SH & Sepeda motor, angkutan umum, sepeda onthel \\
\hline 2 & SC & Sepeda motor, sepeda onthel \\
\hline 3 & VI & Sepeda motor, angkutan umum \\
\hline 4 & IK & Sepeda motor \\
\hline 5 & SP & Sepeda motor, angkutan umum, sepeda onthel \\
\hline 6 & RM & Sepeda motor, angkutan umum, sepeda onthel \\
\hline
\end{tabular}


Sumber: Data Primer diolah, 2018

Tabel 4 dapat diketahui bahwa kendaraan yang digunakan oleh buruh perempuan yang bekerja di bagian grading di PT. Mitratani Dua Tujuh adalah sepeda motor dan angkutan umum. Informan yang memakai angkutan umum sebab lokasi dari rumah informan ke tempat kerja dilalui angkutan umum. Rumah informan VI, RM dan SP berlokasi di Rambipuji, dimana lokasi tersebut dilalui angkutan umum sampai ke lokasi kerja. Lokasi rumah informan SH di Ajung dan juga dilalui angkutan umum sehingga informan kadang-kadang memanfaatkan angkutan umum untuk berangkat ke tempat kerja. Lokasi rumah informan SC di Panti dan tidak dilalui angkutan umum sehingga informan hanya menggunakan sepeda motor saja untuk transportasi ke tempat kerja. Begitu pula dengan informan IK yang lokasi rumah di Tanggul dengan jarak dari rumah ke tempat kerja kurang lebih $20 \mathrm{~km}$, sehingga informan menggunakan sepeda motor sebagai alat transportasi untuk ke tempat kerja.

Berdasarkan penelitian yang dilakukan dapat diketahui bahwa dari alat transportasi yang digunakan oleh informan dalam penelitian yaitu sepeda motor dengan status kepemilikan sendiri, angkutan umum dan sepeda onthel. Informan yang memakai angkutan umum, rata-rata lokasi rumahnya masih dilewati angkutan umum seperti wilayah Rambipuji dan Ajung. Kadang-kadang jika tidak ada yang mengantar, informan yang berlokasi di Rambipuji dan Ajung menggunakan angkutan umum untuk trasnportasi dari rumah ke lokasi kerja. Untuk informan yang lokasi rumah di Tanggul dan Panti yang tidak dilewati angkutan umum mengharuskan informan untuk menggunakan sepeda motor dari rumah ke lokasi kerja. Sepeda onthel dimiliki informan hanya sebagai kendaraan dirumah untuk mobilitas jarak dekat dan digunakan oleh keluarga untuk olahraga sepeda.

\section{Pembahasan}

Kondisi sosial ekonomi merupakan segala sesuatu yang berhubungan dalam hal pemenuhan kebutuhan yang ada di masyarakat atau yang lebih umumnya terkait dengan kesejahteraan masyarakat. Kondisi sosial ekonomi dapat dilihat dari pekerjaan, pendidikan kesehatan dan pemenuhan kebutuhan hidup dalam rumah tangga. Kondisi sosial ekonomi keluarga atau masyarakat dapat digolongkan memiliki sosial ekonomi rendah, sedang dan tinggi (Koejoningrat dalam Zunaidi, 2013:54). Indikator lainnya yang termasuk dalam kondisi sosial ekonomi mencakup berbagai hal yang berkaitan erat dengan pemenuhan kebutuhan seperti pekerjaan, pendapatan, pengeluaran, kesehatan, kepemilikan aset, kredit / pinjaman (dalam Basrowi dan Juariyah, 2010: 61). Indikator kondisi sosial ekonomi yang digunakan pada penelitian ini adalah pendidikan, pendapatan, tempat tinggal dan alat transportasi.

Indikator pertama yaitu pendidikan. Pendidikan buruh perempuan yang bekerja di bagian grading PT. Mitratani Dua Tujuh masih tergolong rendah. Pendidikan tertinggi buruh perempuan yaitu SMA dan pendidikan terendah yaitu SD. Namun, pendidikan anak buruh perempuan sudah maju bahkan ada yang setingkat perguruan tinggi. Hal tersebut menandakan orientasi orang tua terhadap pendidikan anak sudah baik. Buruh perempuan sebagai orang tua berharap anaknya dapat bersekolah tinggi. Adanya orientasi ke masa depan yang baik mengenai pendidikan akan membawa pengaruh yang baik juga bagi peningkatan ekonomi buruh perempuan. Hal tersebut berkaitan dengan fungsi anak dalam pendidikan yaitu dapat diberdayakan untuk membantu pendapatan keluarga. Meskipun pendidikan buruh perempuan rendah, buruh perempuan masih mengusahakan pendidikan anak lebih tinggi dari pendidikan mereka.

Pendidikan buruh perempuan bagian grading di PT. Mitratani Dua Tujuh memiliki pendidikan informal. Pendidikan informal yang didapat mengikuti pelatihan pada saat masa percobaan kerja, karena seorang pekerja baru rata-rata belum mengetahui aturan kerja dan cara bekerja yang diberlakukan oleh perusahaan. Tingkatan pendidikan yang dimiliki oleh buruh perempuan tidak membeda-bedakan perlakuan untuk pekerjaan yang dikerjakan. Bekerja menjadi buruh perempuan memiliki kemudahan karena tidak memerlukan syarat yang rumit seperti pendidikan tinggi dan memiliki keahlian khusus yang mumpuni. Kondisi sosial ekonomi buruh perempuan jika dilihat dari tingkat pendidikannya yaitu termasuk golongan kondisi sosial ekonomi rendah.

Indikator kedua yaitu pendapatan. Pendapatan yang layak adalah pendapatan yang disesuaikan dengan upah minimum. Upah minimum disesuaikan Kebutuhan Hidup Layak (KHL). Kebutuhan Hidup Layak (KHL) adalah standar kebutuhan seseorang pekerja/buruh untuk dapat hidup layak secara fisik dalam 1 bulan (Peraturan Menteri Ketenagakerjaan No 21 Tahun 2016). Pendapatan yang dimaksud dalam penelitian ini yaitu jumlah pendapatan buruh perempuan dalam 1 bulan. Buruh perempuan yang bekerja di bagian grading PT. Mitratani Dua Tujuh diupah Rp 64.000/hari dengan jam kerja kurang lebih 7 jam. Buruh perempuan kadang-kadang ada lemburan jika disuruh oleh perusahaan dengan upah $\mathrm{Rp}$ 10.000.-/jam. Jumlah hari keja buruh perempuan dalam 1 minggu yaitu 6/7 hari. Rata-rata buruh perempuan mendapatkan upah sebesar Rp 1.536.000,-/bulan dengan asumsi buruh perempuan bekerja dalam waktu 24 hari dalam 1 bulan. Menurut Surat Keputusan Gubernur Jawa Timur Nomor 188/665/KPTS/013/2018, UMK Kabupaten Jember sebesar Rp 2.170.917,-. Jika pendapatan buruh dibandingkan dengan UMK Kabupaten Jember, dapat dikatakan bahwa pendapatan masih dibawah UMK. Walaupun pendapatan yang diterima buruh perempuan tersebut di bawah UMK Kabupaten Jember, pendapatan yang diterima masih mencukupi kebutuhan sehari-hari. 
Buruh perempuan bagian grading di PT.Mitratani Dua Tujuh dengan pendapatan diatas UMK Kabupaten Jember dapat dinilai mampu memenuhi kebutuhan keluarganya. Pendapatan yang diperolah buruh perempuan menentukan kondisi sosial ekonominya. Adi (2004:40) menyatakan bahwa penggolongan pendapatan tersebut relevan dengan kondisi sosial ekonomi keluarga/masyarakat. Kriteria penggolongan pendapatan dapat dijelaskan sebagai berikut: a) Golongan berpenghasilan rendah, yaitu keluarga yang menerima pendapatan lebih rendah dari keperluan untuk memenuhi tingkat hidup yang minimal; b) Golongan berpenghasilan sedang, yaitu pendapatan yang hanya cukup untuk memenuhi kebutuhan pokok; dan c) Golongan berpenghasilan tinggi, yaitu keluarga yang menerima pendapatan selain bisa memenuhi kebutuhan pokok, sebagian pendapatan yang diterima dapat ditabung. Hal tersebut dapaat disimpulkan bahwa kondisi sosial ekonomi buruh perempuan jika dilihat dari pendapatan keluaarga termasuk golongan kondisi sosial ekonomi sedang.

Indikator ketiga yaitu tempat tinggal. Kondisi rumah buruh perempuan rata-rata permanen. Status kepemilikan rumah buruh perempuan bermacam-macam ada yang milik pribadi, milik orang tua dan ada yang tinggal bersama orang tua. Luas rumah buruh perempuan yaitu $36 \mathrm{~m} 2,54 \mathrm{~m} 2$ dan $56 \mathrm{~m} 2$. Kondisi rumah dapat mencerminkan kondisi sosial ekonomi buruh perempuan. Status kepemilikan rumah yang ditempati milik sendiri dan kondisi fisik bangunan permanen dapat menunjukkan bahwa keluarga tersebut termasuk golongan kondisi sosial ekonomi tinggi. Hal tersebut serupa dengan pernyataan Sumardi (dalam Wijianto dan Ulfa, 2016: 194) untuk mengukur tingkat sosial ekonomi seseorang dari rumahnya, dapat dilihat dari: a) Status rumah yang ditempati, bisa rumah sendiri, rumah dinas, menyewa, menumpang pada saudara atau ikut orang lain; b) Kondisi fisik bangunan dapat berupa permanen, kayu dan bambu; c) Besarnya rumah yang ditempati, semakin luas rumah yang ditempati pada umumya semakin tinggi tingkat sosial ekonominya. Ciri rumah yang tergolong permanen yakni bangunan rumah yang sudah kokoh, dindingnya terbuat dari tembok, lantainya terbuat dari keramik dan atapnya terbuat dari genteng.

Rata-rata kondisi rumah yang ditempati sudah permanen. Status kepemilikan rumah buruh perempuan ada yang milik sendiri dan orang tua. Namun, untuk luas bangunan rumah buruh perempuan masih tergolong minimalis. Luas minimal bangunan yang ditetapkan Kementerian PUPR ( Pekerjaan Umum dan Perumahan Rakyat ) No 1 Tahun 2018 yaitu 36 m2 yang menunjukkan bahwa luas bangunan rumah sederhana yang layak dihuni. Sumardi (dalam Wijianto dan Ulfa, 2016: 194) mengatakan bahwa jika semakin luas rumah yang ditempati menunjukkan semakin tinggi tingkat sosial ekonominya. Namun, dalam penelitian ini dengan kepemilikan rumah milik sendiri maupun orang tua, kondisi permanen dan luas bangunan minimalis sebagai buruh perempuan pendapatan yang diterima hanya cukup untuk memenuhi kebutuhan pokok keluarga. Kondisi sosial ekonomi buruh perempuan dilihat dari kondisi rumah, buruh perempuan termasuk golongan kondisi sosial ekonomi sedang.Rata-rata kondisi rumah yang ditempati sudah permanen. Status kepemilikan rumah buruh perempuan ada yang milik sendiri dan orang tua. Namun, untuk luas bangunan rumah buruh perempuan masih tergolong minimalis. Luas minimal bangunan yang ditetapkan Kementerian PUPR ( Pekerjaan Umum dan Perumahan Rakyat ) No 1 Tahun 2018 yaitu 36 m2 yang menunjukkan bahwa luas bangunan rumah sederhana yang layak dihuni. Sumardi (dalam Wijianto dan Ulfa, 2016: 194) mengatakan bahwa jika semakin luas rumah yang ditempati menunjukkan semakin tinggi tingkat sosial ekonominya. Namun, dalam penelitian ini dengan kepemilikan rumah milik sendiri maupun orang tua, kondisi permanen dan luas bangunan minimalis sebagai buruh perempuan pendapatan yang diterima hanya cukup untuk memenuhi kebutuhan pokok keluarga. Kondisi sosial ekonomi buruh perempuan dilihat dari kondisi rumah, buruh perempuan termasuk golongan kondisi sosial ekonomi sedang.

Indikator keempat yaitu alat trasnportasi. Indikator alat transportasi yang digunakan dalam penelitian ini yaitu kepemilikan alat transportasi yang meliputi milik sendiri atau bukan milik sendiri, jenis alat transportasi yang dimiliki seperti mobil atau motor dan kemudahan dalam menggunakan transportasi umum. Indikator yang digunakan serupa dengan pendapat Badan Pusat Statistik (2003) menyatakan bahwa indikator kemudahan mendapatkan fasilitas alat transportasi meliputi kepemilikan alat transportasi, fasilitas alat transportasi serta ongkos dan biaya. Buruh perempuan rata-rata menggunakan sepeda motor dan angkutan umum sebagai alat transportasi. Sepeda motor yang digunakan buruh perempuan rata-rata status kepemilikannya milik sendiri. Angkutan umum digunakan oleh buruh perempuan apabila tidak ada sepeda motor untuk mobilitas ke lokasi kerja. Tidak semua buruh menggunakan angkutan umum karena angkutan umum hanya melewati lokasi-lokasi tertentu seperti Rambipuji dan Ajung. Buruh perempuan ada yang memiliki sepeda onthel,sepeda onthel digunakan hanya untuk mobilitas jarak dekat dengan rumah dan dipakai untuk olahraga sepeda oleh keluarga.

Sebagai buruh perempuan, pendapatan yang diterima dikatakan cukup untuk memenuhi kebutuhan pokok keluarga. Memiliki kendaraan sepeda motor sebagai buruh perempuan merupakan suatu kebutuhan yang menunjang mobilitas keluarga dalam kehidupan sehari-hari. Jika dilihat dari alat transportasi yang digunakan oleh keluarga, kondisi sosial ekonomi buruh perempuan termasuk dalam golongan kondisi sosial ekonomi sedang.

\section{PENUTUP}

Berdasarkan hasil penelitian dan pembahasan, maka dapat diambil kesimpulan bahwa kondisi sosial 
ekonomi buruh perempuan yang bekerja di bagian grading PT. Mitratani Dua Tujuh dapat dilihat dari 4 indikator yaitu pendidikan, pendapatan, tempat tinggal dan alat transportasi termasuk golongan kondisi sosial ekonomi sedang. Kondisi ekonomi informan dilihat dari indicator pendidikan yaitu termasuk golongan kondisi sosial ekonomi sedang, buruh perempuan yang bekerja di PT. Mitratani Dua Tujuh rata-rata lulusan SD hingga SMA. Pendapatan buruh perempuan di PT. Mitratani Dua Tujuh rata-rata masih dibawah UMK Kabupaten Jember sebesar Rp 2.170.917 yaitu bekisar Rp 1.536.000, namun dengan pendapatan tersebut dapat dinilai masih mencukupi kebutuhan keluarga sehari-hari. Kondisi tempat tinggal buruh perempuan di PT. Mitratani Dua Tujuh yaitu kondisi bangunan permanen, status kepemilikan ada yang milik sendiri dan orang tua serta luas bangunan rata-rata $36 \mathrm{~m} 2$. Alat transportasi yang digunakan buruh perempuan di PT. Mitratani Dua Tujuh yaitu sepeda motor, angkutan umum dan sepeda onthel. Saran dapat diberikan kepada pihak terkait yaitu buruh perempuan di PT. Mitratani Dua Tujuh untuk mengikuti pelatihan yang diadakan pemerintah setempat untuk mengembangkan kreatifitas yang memiliki nilai jual yang berguna untuk menambah pendapatan yang diterima selain bekerja menjadi buruh.

\section{DAFTAR PUSTAKA}

Adi. 2004. Metodologi Penelitian Sosial dan Hukum. Jakarta: Granit.

Badan Pusat Statistik. 2003. Indikator Kesejahteraan Rakyat. Jakarta: BPS.

Badan Pusat Statistik. 2018. Kebutuhan Hidup Minimum Menurut Provinsi [serial online] https://www.bps.go.id/linkTableDinamis/view/id/1212diakses pada tanggal 16 April 2018.

Basrowi dan S. Juariyah. 2010. Analisis Kondisi Sosial Ekonomi dan Tingkat Pendidikan Masyarakat Desa Srigading, Kecamatan Labuhan Maringgai Kabupaten Lampung Timur. Jurnal Ekonomi dan Pendidikan: $7(1)$

Dalyono. 2005.Psikologi Pendidikan. Jakarta. Rineka Cipta

Dewi, Putu Martini. 2012. Partisipasi Tenaga Kerja Perempuan dalam Meningkatkan Pendapatan Keluarga..Jurnal Ekonomi Kuantitaif Terapan.

Pratomo, S. D dan P. Mahardika Adi Saputra. 2011. Kebijakan Upah Minimum UntukPerekonomian Yang Berkeadilan: Tinjauan UUD 1945. Journal of Indonesian Applied economics: 5(2)

Semiawan, Conny R. 2010. Metode Penelitian Kualitatif. Jakarta: Grasindo

Republik Indonesia. 2003. Undang-Undang Nomor 21 Tahun 2016 Tentang Ketenagakerjaan. Sekretariat Negara. Jakarta 